This article was downloaded by: [New York University]

On: 26 April 2015, At: 06:21

Publisher: Routledge

Informa Ltd Registered in England and Wales Registered Number: 1072954

Registered office: Mortimer House, 37-41 Mortimer Street, London W1T

3J H, UK

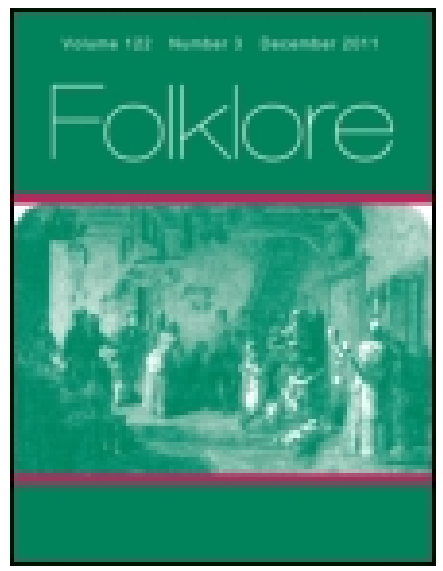

\title{
Folklore
}

Publication details, including instructions for authors and subscription information:

http:// www. tandfonline.com/loi/ rfol20

\section{Manx Folk-Lore and Superstitions. II}

J. Rhys

Published online: 14 Feb 2012.

To cite this article: J. Rhys (1892) Manx Folk-Lore and Superstitions. II, Folklore, 3:1, 74-91, DOI: 10.1080/ 0015587X. 1892.9720091

To link to this article: http:// dx. doi.org/ 10.1080/0015587X.1892.9720091

\section{PLEASE SCROLL DOWN FOR ARTICLE}

Taylor \& Francis makes every effort to ensure the accuracy of all the information (the "Content") contained in the publications on our platform. However, Taylor \& Francis, our agents, and our licensors make no representations or warranties whatsoever as to the accuracy, completeness, or suitability for any purpose of the Content. Any opinions and views expressed in this publication are the opinions and views of the authors, and are not the views of or endorsed by Taylor \& Francis. The accuracy of the Content should not be relied upon and should be independently verified with primary sources of information. Taylor and Francis shall not be liable for any losses, actions, claims, proceedings, demands, costs, expenses, damages, and other liabilities whatsoever or howsoever caused arising directly or indirectly in connection with, in relation to or arising out of the use of the Content.

This article may be used for research, teaching, and private study purposes. Any substantial or systematic reproduction, redistribution, reselling, loan, sub-licensing, systematic supply, or distribution in any form to anyone is 
expressly forbidden. Terms $\&$ Conditions of access and use can be found at http://www.tandfonline.com/page/terms-and-conditions 


\section{$M A N X$}

FOLK-LORE AND SUPERSTITIONS.

II.

$T^{N}$ my previous paper I made allusion to several wells of 1 greater or less celebrity in the Island; but I find that I have a few remarks to add. Mr. Arthur Moore, in his book on Mante Sumames and Place-Names, p. 200, mentions a Chibber Unjin, which means the Well of the Ash. tree, and he states that there grew near it "formerly a sacred ash-trec, where votive offerings were hung". The ash-trce calls to his mind Scandinavian legends respecting the ash, but in any case one may suppose the ash was not the usual tree to expect by a well in the Isle of Man, otherwise this one would scarcely have been distinguished as the Ash-tree Well. The tree to expect by a sacred well is doubtless some kind of thorn, as in the case of Chibber Undin in the parisl of Malew. The name means Foundation Well, so called in reference probably to the foundations of an ancient cell, or kecill as it is called in Manx, which lic close by, and are found to measure 21 fect long by 12 fect broad. The following is Mr. Moore's account of the well in his book already cited, p. 181 : "The water of this well is supposed to have curative propertics. The patients who came to it, took a mouthful of water, retaining it in thcir mouths till they had twice walked round the well. They then took a piece of cloth from a garment which they had worn, wetted it with the water from the well, and hung it on the hawthorn-tree which grew there. When the cloth had rotted away, the cure was supposed to be effected." 
I visited the spot a few years ago in the company of the Rev. E. B. Savage of St. Thomas's Parsonagc, Douglas, and we found the well nearly dried up in consequence of the drainage of the field around it; but the remains of the old cell were there, and the thorn-bush had strips of cloth or calico tied to its branches. We cut off one, which is now in the Pitt-Rivers Muscum at Oxford. The account Mr. Savage had of the ritual observed at the well differed a little from that given by Mr. Moore, especially in the fact that it made the patient who had been walking round the well with water from the well in his mouth, empty that water finally into a rag from his clothing: the rag was then tied to a branch of the thorn. It does not appear that the kind of tree mattered much; nay, a trce was not, it scems to me, essential. At any ratc, St. Maughold's Well has no tree growing near it now; but it is right to say, that when Mr. Kermode and I visited it, we could find no rags left near the spot, nor indecd could we expect to find any, as there was nothing to which they might be ticd on that windy headland. The absence of the tree does not, however, prove that the same sort of ritual was not formerly observed at St. Maughold's Well as at Chibber Undin; and here I must mention another well which 1 have visited in the Island more than once. It is on the side of Bradda Hill, a little above the village of Bradda, and in the direction of Fleshwick: I was attracted to it by the fact that it had, as I had been told by Mr. Savage, near it formerly an old cell or kiceill, and the name of the saint to which it belonged may probably be gathered from the name of the well, which, in the Manx of the south of the Island, is Chibbyrt Valtane, pronounced approximately Chürurt Valtáne or Alđáne. The personal name would be written in modern Manx in its radical form as Baltanc, and if it occurred in the genitive in old inscriptions I should expect to find it written Baltagni. It is, however, unknown to me, but to be placed by the side of the name of the saint after whom the parish of Santon is called in the 
south-cast of the island. This is pronounced in Manx approximately ${ }^{1}$ Santane or Sanðane, and would have yielded an carly inscriptional nominative Sanctagnus, which, in fact, occurs on an old stone near Llandudno on the opposite coast: sce Rhys's Lectures on Welsh Philology, p. $371^{2}$. To return to the well, it would seem to have been associated with an old cell, but it has no tree growing by it. Mr. Savage and I were told, nevertheless, that a boy who had scarched a short time previously had got some coins out of it, quite recent ones, consisting of halfpennies or pennics, so far as 1 remember. On my observing to one of the neighbours that I saw no rags there, I was assured that there had been some; and, on my further saying that I saw no tree there to which they could be tied, I was told that they used to be attached to the brambles, which grew there in great abundance. Thus it appears to me that, in the Isle of Man at any rate, a tree to bear the rags was not an essential adjunct of a holy well.

There is another point to which I should like to call attention, namely, the habit of writing about the rags as offerings, which they are not in all cases. The offerings are the coins, bcads, buttons, or pins thrown into the well, or placed in a receptacle for the purpose close to the well. The rags may belong to quite a different order of things : they may be the vehicles of the discases which the patients communicate to them when they spit out the well-water from their mouths. The rags are put up to rot, so that the discasc supposed to cling to them may also dic; and so far is this believed to be the case, that anyone who carrics away one of the rags may expect to

1 I say 'approximately', as, more strictly speaking, the ordinary pronunciation is SnJăen, almost as one syllable, and from this arises a variant, which is sometimes written Stondane, while the latest English development, regardless of the accentuation of the AngloManx form Santon (pronounced Sántn), makes the parish into a St. Ann's 1 For the evidence that it was the parish of a St. Sanctan (or Sanctagnus), see Moore's Surnames, p. 209. 
attract the discase communicated to it by the one who left it near the holy well. So it is highly desirable that the distinction between the offerings and the accursed things should be observed, at any rate in writing of holy wells in the Isle of Man. How far the same distinction is to be found elscwhere I am unable to say; but the question is one which deserves attention.

From the less known saints laaltane and Santane I wish to pass to the mention of a more famous one, namely, St. Catherine, and this because of a fair called after her, and held on the 6th day of December at the village of Colby in the south of the Island. When I heard of this fair in 1888, it was in temporary abcyance on account of a lawsuit respecting the plot of ground on which the fair is wont to be held; but I was told that it usually began with a procession, in which a live hen is carricd about: this is called St. Catherine's hen. The next day the hen is carricd about dead and plucked, and a rhyme pronounced at a certain point in the procecding contemplates the burial of the hen, but whether that ever took place I know not. It.runs thus :

" Kiark Catrina marroo:

Gorus yn kione as goyms ny cassyn, As ver mayd ce fo'n thalloo."

"Cathrine's hen is dead :

The head take thou and I the feet, And we shall put her under ground."

A man who is found to be not wholly sober after the fair is locally said to have plucked a feather from the hen (Telt er goaill fedjag ass $y$ chiark); so it would seem that there must be such a scramble to get at the hen, and to take part in the plucking, that it requires a certain amount of drink to allay the thirst of the over-zcalous devotecs of St. Catherine. But why should this cercmony be associated with St. Catherine? and what were the 
origin and meaning of it? These are questions which I should be glad to have expounded by the Society, for I have not had time to consult Mr. Fraser's Golden Bough, in order to see if it gives any close parallel to the proceedings of the good people of Colby.

Manx has a word quaail (Irish comldhdil), meaning a 'mecting', and from it we have a derivative quaaltagh or qualtagh, meaning, according to Kelly's Dictionary, "the first person or creature one meets going from home", whercby the author probably meant the first person met by one who is going from home. Kelly goes on to add that "this person is of great consequence to the superstitious, particularly to women the first time they go out after lying-in". Cregecn, in his Dictionary, defines the qualtagh as "the first person met on New Year's Day, or on going on some new work, ctc." Before proceeding to give you my notes on the qualtagh of the present day I may as well finish with Cregeen, for he adds the following information: "A company of young lads or men, generally went in old times on what they termed the Qualtagh, at Christmas or New Year's Day, to the houses of their more wealthy neighbours; some one of the company repeating in an audible voice the following rhyme:-

"Ollick ghennal erriu as blein feer vie, Seihll as slaynt da'n slane lught thie ;

Bea as gennallys eu bio ry-cheilley, Shee as graih eddyr mrane as deiney;

Cooid as cowryn, stock as stoyr, Palchey phuddase, as skaddan dy-liooar;

Arran as caashcy, eeym as roayrt;

Baase, myr lugh, ayns uhllin ny soalt;

Cadley sauchey tra vecs shiu ny lhie, As feeackle y jargan, nagh bee dy mie."

It may be looscly translated as follows :-

"A merry Christmas, a happy new year, Long life and health to the household here. 
Food and mirth to you dwelling together,

Peace and love to all, men and women ;

Wealth and distinction, stock and store,

Potatoes enough, and herrings galore;

Bread and cheese, butter and plenty,

Death, like a mouse, in a barn or haggard;

Sleep in safety while down you lie,

And the flea's tooth-may it not badly bite."

At present Ncw Year's Day is the time when the qualtagh is of general interest, and in this case he is practically the first person one sees (besides the members of one's own houschold) on the morning of that day, whether that person mects one out of doors or comes to one's house. The following is what I have learnt by inquiry as to the qualtagh : all are agreed that he must not be a woman or girl, and that he must not be spaagagh or splay-footed, while a woman from the parish of Marown told me that he must not have red hair. The prevalent belief, however, is that he should be a dark-haired man or boy, and it is of no consequence how rough his appearance may be, provided he be black-haired. However, I was told by one man in Rushen that the qualtagh need not be blackhaired : he must be a man or boy. But this less restricted view is not the one held in the central and northern parts of the Island, so far as I could ascertain. An English lady living in the neighbourhood of Castletown told me that her son, whom I know to be, like his mother, a pronounced blond, not being aware what consequences might be associated with his visit, called at a house in Castletown on the morning of New Year's Day, and he chanced to be the qualtagh. The mistress of the house was horrified, and cxpressed her anticipation of misfortunes to the English lady; and as it happened that one of the children of the house died in the course of the year, the English lady has heard of it since. Naturally the association of these events are not pleasant to her; but, so far as 1 can remember, they date only some eight or nine years ago. 
The Socicty may have published information on this subject, but I am at present utterly ignorant what importance the qualtagh may have enjoyed in other parts of the British Isles. As to Wales, I can only recall, that, when I was a very small boy, I used to be sent very early on Ncw Ycar's morning to call on an old uncle of mine, becausc, as I was told, I should be certain to receive a calcmitg or a calendary gift from him, but on no account would my sister be allowed to go, as he would only see a boy on such an occasion as that. I do not recollect anything being said as to the colour of one's hair or the shape of onc's foot; but that sort of negative evidence is of very little valuc, as the qualtagh was fast passing out of consideration.

The preference here given to a boy over a girl looks like one of the widcly-spread superstitions which rule against the fair sex; but, as to the colour of the hair, I should be predisposed to think that it possibly rests on racial antipathy, long ago forgotten ; for it may perhaps be regarded as going back to a time when the dark-haired race reckoned the Aryan of fair complexion as his natural enemy, the very sight of whom brought with it thoughts calculated to make him unhappy and despondent. If this idea prove to be approximately correct, one might suggest that the racial distinction in question referred to the struggles between the inhabitants of Man and thcir Scandinavian conquerors; but to my thinking it is just as likcly that it gocs far further back.

Lastly, what is one to say with regard to the spaagagh or splay-footed person, now more usually defined as flatfooted or having no instep? I have heard it said in the south of the Island that it is unlucky to mect a spaagagh in the morning at any time of the ycar, and not on New Ycar's Day alone; but this does not help us in the attempt to find the genesis of this belief. If it were said that it was unlucky to mect a deformed person, it would look somcwhat more natural; but why fix on the flat-footed 
especially? For my part I have not been trained to distinguish flat-footed people, so I do not recollect noticing any in the Isle of Man; but, granting there may be a small proportion of such pcople in the Island, does it not seem to you strange that they should have their importance so magnificd as this supcrstition would secm to do? I must confess that I cannot understand it, unless we have here also some supposed racial characteristic, let us say greatly exaggerated. To explain myself I should put it that the non-Aryan aborigines were a small people of great agility and nimblencss, and that their Aryan conquerors moved more slowly and deliberately, whence the former, of springier movements, might come to nickname the latter the flat-fect. It is cren conceivable that there was some amount of foundation for it in fact. If I might speak from my own cxperience, I might mention a difficulty I have often had with shocs of English make, namcly, that I have always found them, unless made to my measurc, apt to have their instep too low for mc. It has never occurred to me to buy ready-made shocs in France or Germany, but I know a lady as Welsh as myself who has often bought shoes in France, and her experience is, that it is much easier for her to get shoes there to fit her than in England, and for the very reason which I have alrcady suggested, namely, that the instep in English shoes is lower than in French ones. These two instances do not warrant an induction that the Celts are higher in the instep than Teutons, and that they have inherited that characteristic from the non-Aryan element in their ancestry; but they will do to suggest a question, and that is all I want: Are the descendants of the non-Aryan aborigines of these islands proportionately higher in the instep than those of morc purcly Aryan descent?

There is one other question which I should like to ask before leaving the qualtagh, namely, as to the relation of the custom of New Year's gifts to the belief voln ilt. 
in the qualtagh. I have heard it related in the Isle of Man that women have been known to keep indoors on Now Year's Day until the qualtagh comes, which sometimes means their being prisoners for the greater part of the day, in order to avoid the risk of first mecting one who is not of the right sex and complexion. On the other hand, when the qualtagh is of the right description, considcrable fuss is made of him; to say the least, he has to accept food and drink, possibly more permanent gifts. Thus a tall, black-haired native of Kirk Michael described to me how he chanced on Ncw Year's Day years ago to turn into a lonely cottage in order to light his pipe, and how he found he was the qualtagh: he had to sit down to have food, and when he went away it was with a present and the blessings of the family. Now New Year's Day is the time for gifts in Wales, as shown by the name for them, calennig, which is derived from calan, the Welsh form of the Latin calenda, Ncw Year's Day being in Welsh $Y$ Calin, 'the Calends'. The same is the day for gifts in Scotland and in Ircland, except in so far as Christmas. boxes have been making inroads from England; I nced not add that the Jour de l'An is the day for gifts also in France. My qucstion then is this: Is there any connection of origin between the institution of New Year's Day gifts and the belicf in a qualtagh?

Now that it has been indieated what sort of a qualtagh it is unlucky to have, I may as well procced to mention the other things which I have heard treated as unlucky in the Island. Some of them scarcely require to be noticed, as there is nothing specially Manx about them, such as the belief that it is unlucky to have the first glimpse of the new moon through glass. That is a superstition which is, I believe, widely spread, and, among other countries, it is quite familiar in Wales. It is also believed in Man, as it used to be in Wales and Ircland, that it is unlucky to disturb antiquitics, espccially old burial-places and old churches. 
This supcrstition is unfortunately fast passing away in all three countrics, but you still hear of it, especially in the Isle of Man, after some mischief has been done. Thus a good Manx scholar told me how a relative of his in the Ronnag, a small valley near South Barrule, had carted the carth from an old burial-ground on his farm and used it as manure for his ficlds, and how his bcasts died afterwards. The narrator said he did not know whether there was any truth in it, but everybody believed that it was the reason why the cattle died; and so did the farmer himself at last: so he desisted from complcting his disturbance of the old site. It is possibly for a similar reason that a housc in ruins is seldom pulled down and the materials used for other buildings: where that has been done misfortunes have ensued: at any rate, I have heard it said more than once. I ought to have stated that the nondisturbance of antiquities in the Island is quite consistent with their being now and then shamefully neglected as elsewhere: this is now met by an excellent statute recently enacted by the House of Keys for the preservation of the public monuments in the Island.

Of the other and more purely Manx superstitions I may mention one which obtains among the Pecl fishermen of the present day: no boat is willing to be third in the order of sailing out from Pecl harbour to the fisheries. So it sometimes happens that after two boats have departed, the others remain watching each other for days, each hoping that somebody else may be reckless enough to break through the invisible barricr of 'bad luck'. I have often asked for an explanation of this superstition, but the only intelligible answer I have had was that it has been obscrved that the third boat has done badly several years in succession; but I am unable to ascertain how far that represents a fact. Another of the unlucky things is to have a white stone in the boat, even in the ballast, and for that I never could get any cxplanation at all; but there is no doubt as to the fact of this superstition, and I may illus- 
trate it from the case of a clergyman's son on the west side, who took it into his head to go out with some fishermen several days in succession. They chanced to be unsuccessful cach time, and they gave their Jonah the nickname of Clagh Vane or 'White Stone'. Here I may mention a fact which I do not know where else to put, namcly, that a fisherman on his way in the morning to the fishing, and chancing to pass by the cottage of another fisherman who is not on friendly terms with him, will pluck a straw from the thatch of the latter's dwelling. Thereby he is supposed to rob him of luck in the fishing for that day. One would expect to learn that the straw from the thatch served as the subject of an incantation directed against the owner of the thatch, but I have never heard anything suggested to that effect: so I conclude that the plucking of the straw is only a partial survival of what was once a complete ritual for bewitching one's ncighbour.

Owing to my ignorance as to the superstitions of other fishermen than those of the Isle of Man, I will not attempt to classify the remaining instances to be mentioned, such as the unluckiness of mentioning a horse or a mouse on board a fishing-boat: I seem, however, to have heard of similar taboos among Scotch fishermen. Novices in the Manx fisheries have to learn not to point to anything with one finger: they have to point with the whole hand or not at all. Whether the Manx are alone in thinking it unlucky to lend salt from one boat to another when they are: engaged in the fishing, I know not: such lending would probably be inconvenient, but why it should be unlucky, as they belicve it to bc, docs not appear. The first of May is a day on which it is unlucky to lend anything, and especially to give anyone firc. This looks as if it pointed back to some Druidic custom of lighting all fires at that time from a sacred hearth, but, so far as is known, this only took place at the beginning of the other half-year 
namely, Allhallows, called in Manx Laa 'll mooar $n y$ Saintsh, 'the Day of the great Feast of the Saints'.

Lastly, I may mention that it is unlucky to say that you are very well : at any rate, I infer that it is regarded so, as you will never get a Manxman to say that he is fecr vic, 'very well'. He usually admits that he is 'middling'; and if by any chance he risks a stronger adjective, he hastens to qualify it by adding 'now' or 'just now', with an emphasis indicative of his anxiety not to say too much. His habits of specch point back to a time when the Manx mind was dominated by the fear of awaking malignant influences in the spirit-world around him. This has had the effect of giving the Manx peasant's character a tinge of reserve and suspicion, which makes it difficult to gain his confidence : his acquaintance has, thercfore, to be cultivated for some time before you can say that you know the workings of his heart. The pagan belief in a Nemesis has doubtless passed away, but not without materially affecting the Manx idca of a personal devil. Ever since the first allusion made in my presence by Manxmen to the devil, I have been more and more decply impressed that the Manx devil is a much more formidable being than Englishmen or Welshmen picture him. He is a graver and, if I may say so, a more respectable being, allowing no liberties to be taken with his name, so you had better not call him a Devil, the Evil Onc, or like names, for his proper designation is Noid ny Hanmey, 'the Enemy of the Soul', and in ordinary Anglo-Manx conversation he is commonly called 'the Enemy of Souls'. The Manx arc, as a rulc, a sober people, and highly religious; as regards their theological views, they are mostly members of the Church of England or Wesleyan Methodists, or else both, which is by no means unusual. Religious phrases are not rare in their ordinary conversation; in fact, they struck me as being of more frequent occurrence than in Wales, even the Wales of my boyhood; and here and 
there this fondness for religious phraseology has left its traces on the native vocabulary. Take, for example, the word for 'anybody, a person, or human being', which Cregeen writes $p y^{\prime} a g / h$ or $p^{\prime} a g / t:$ he rightly regards it as the colloquial pronunciation of peccaglt, 'a sinner'. So, whan onc knocks at a Manx door and calls out, Vcl p'agh sthie? he strictly speaking asks, 'Is there any sinner indoors?' The question has, however, been explained to me, with unconscious irony, as properly meaning 'Is there any Christian indoors?' and care is now taken in reading to pro. nounce the consonants of the word peccagh, 'sinner', so as to distinguish it from the word for 'anybody': but the identity of origin is unmistakable.

Lastly, the fact that a curse is a species of prayer, to wit, a praycr for cvil to follow, is well excmplified in Manx by the same words gwee and grwecagliyn meaning both kinds of praycr. Thus I found mysclf stumbling scveral times, in reading through the Psalms in Manx, from not bearing in mind the sinister meaning of these words; for cxample, in Ps. xiv, $\sigma$, where we have $T a$ ' $n$ beeal oc lane dy gluwcengliyn as dy herriuid, which I mechanically construcd to mean "Thcir mouth is full of praying and bittcrness", instcad of "cursing and bitterness"; and so in other cascs, such as Ps. $x, 7$, and cix, 27.

It occurred to me on various occasions to make inquirics as to the attitude of religious Manxmen towards witchcraft and the charmer's vocation. Nobody, so far as 1 know, accuscs them of favouring witcheraft in any way whatsocver; but I have heard it distinctly stated that the must religious men are they who have most confidence in charmers and their charms; and a lay preacher whom I know has been mentioned to me as now and then doing a little charming in cases of danger or pressing need. On the whole, I think the charge against religious people of

1 Old-fashioned grammarians and dictionary makers are always delighted to handle Mrs. Partington's broom : so Kelly thinks he has done a fine thing by printing $g$ uee, 'prayer', and gwee, 'cursing.' 
consulting charmers is exaggerated; but I believe that recourse to the charmer is more usual and more openly had than, for example, in Walcs, where those who consult a dyn hyspys or 'wise man' have to do it sccretly, and at the risk of being expelled by their co-religionists from the Seiet or 'Society'. There is somewhat in the atmosphere of Man to remind one rather of the Wales of a past generation, the Wales of the Rev. Edmund Jones, author of a Relation of Apparitions of Spirits in the County of Monmouth and the Principality of Wales (Newport, 1813), a book which its author tells us was "designed to confute and to prevent the infidelity of denying the being and apparition of spirits, which tends to irreligion and atheism". That little volume not only deserves to be known to the Psychical Socicty, but it might be consulted with a certain amount of advantage by folk-lorists.

The Manx peasantry are perhaps the most independent and prosperous in the British Isles; but their position gcographically and politically has been favourable to the continuance of idcas not quite up to the level of the latest papers on Darwinism and Evolution read at our Church Congresses in this country. This you may say is here wide of the mark; but, after giving you in my first paper specimens of rather ancient superstitions as recently known in the Island, it is but right that you should have an idea of the surroundings in which they have lingered into modern times. Perhaps nothing will better serve to bring this home to your minds than the fact, for which there is abundant cvidence, that old people still living remember men and women clad in white sheets doing penance publicly in the churches of Man. Some of the penitents have only been dead some six or seven years, nay, it is possible, for anything I know, that one or two may be still alive. This scems to us in this country to belong, so to say, to ancient history, and it transports us to a state of things which we find it hard to realisc. The lapse of years has brought about profounder changes in our greater Isle of 
Britain than in the smaller Isle of Man; and we, failing ourselves to escape the pervading influences of those profounder changes, become an instance of the comprehensive truth of the words,

Tempora mutantur nos et mutamur in illis.

J. RHYS.

\section{Discussion.}

Dr. KARL BLIND: Prof. Rhys is right in stating that the ashtree may be referred to the great ash-tree of Scandinavian mythology; that it symbolizes the Universe, as described in Eddaic days. The well, whose water is exceedingly pure, reminds us of the fountains that lie at the root of the Scandinavian ash-trce, and in the Edda it is said that it is as pure and white as the shell of an egg.

If I have rightly understood Prof. Rhys, a sacred thorn-bush is also mentioned. That would remind us of the worship of the thorn-bush in Teutonic literature. The thorn-bush is very much used among the Teutons for crematory purposes. No one was allowed to clip or go near them. Brand, in his Popular Antiquities, mentions such a thorn-bush in Scotland.

The well-worship was a familiar worship of our Scandinavian ancestors. It is easily understood why it should prevail very much in the Isle of Man.

As to the red-haired man: this refers to the Scandinavian conquerors of the older people of Iberian descent in the Isle of Man. These aborigines had still a fear of the red-haired man who had conquered them. The Isle of Man is full of names corresponding to Scandinavian. The people afterwards became Celticised in speech, but very often examples occur with the Germanic type.

Prof. Rhys sajs that the superstition about red-haired men may be found further back than the Scandinavian conquest of the Island. I have no doubt whatever that in very ancient times there has been wave after wave of Teutonic migration and emigration along the shores of Scotland. There are no doubt traces in 
poems that refer to older conquests of Man. The first movement was always towards Ireland and then went back to Scotland. In the Isle of MIan a great deal is spoken of the "little people", and the little people (as I hear from my daughter and son-in-law, who have visited the Island) are still worshipped there. Many inhabitants go to bed on stormy days to allow the little people to have refuge comfortably. The little people mean doubtless the Iberian aborigines.

$\Lambda s$ to the instep, I can speak from personal experience. Al. most every German finds that an English shoemaker makes his boots not high enough in the instep. The northern Germans (I am from the south) have perhaps slightly flatter feet than the southern Germans.

With regard to the prohibition to carry manure from churchjards, a sanitary idea lingers under it, though doubtless connected with religious ideas as in other cases. In cat-lore, e.g., there is a great deal of scientific knowledge with regard to change of temperature, people having closely observed the manners of cats under different atmospheric conditions, and being able to tell, therefore, whether storm is brewing or fine weather coming on. In certain cases of diseascs, such as small-pox for instance, the carrying of manure would certainly become fatal to beast or man.

Horse, mouse, etc., on board ship are held to be fatal, and they must be mentioned under other names. Shetland fishermen will not mention a church or a clergyman (the latter being especially unlucky) on board ship. They use quite other names on board.

A Mlanx man will not speak of himself as being very well. That superstition is all over the world. The Germans have the expression beschrcien. You must not mention a thing too favourably; you are punished for too great exuberance of joy.

It is a mistake to think the Scandinavians did not bring any of their women with them. They are often mentioned in the sagas.

Mr. Gomme: IVith reference to well-superstitions, a very interesting suggestion made by Prof. Rhys is that rags are not offerings, but are put there for the cure of diseases. There is some cvidence ayainst that, from the fact that in the case of some wells, especially in Scotland at one time, the whole garment was put down as an offering. Gradually these offerings of clothes became 
less and less till they came down to rags. Also in other parts, the geographical distribution of rag-offerings coincides with the existence of monoliths and dolmens. Though the Manx evidence goes against the more general conclusion, it is important to emphasise it. The absence of the tree in connection with wellworship is a very interesting subject. Where we find in England no tree, the rag-well gives way to the pin-well, and as the trees are worn away the pin, as another part of dress, is substituted.

As to the first-foot on New Year's Day, Prof. Rhys seemed to distinguish between the three different objects which were unlucky -a woman, red-haired, and splay-footed people. Red hair and splay-foot might be matters of race. Why not go a little bit further, and say the case of the woman is also a matter of race? Mr. Stuart-Glennie's matriarchy theory is based on the fact of many tribes marrying women of different races. Two elements of the first-foot superstition may be put down as racial, why not the third?

As to lighting of fire from one central fire, there is the belief that if no fire were found some great misfortune would happen. Fire-worship, Canon Taylor asserts, is not Aryan at all, but Ibcrian. $\Lambda$ s to fires being lighted from a common centre, I should like to see the Society take up the subject as one to investigatc. It is found in all parts where Celtic holding has been most lasting. Fires of the houschold are lighted from that beltan fire on a particular day. There is a superstition against not lighting from that particular fire. It is evident that Prof. Rhys has obscrved with very great attention. I should like to put this question before him.

Mr. Nutr: As to the qualtagh, I have been thrown into an occan of perplexity, first by Irof. Rhys and secondly by Mr. Gomme. It would scem from Prof. Rhys that the unlucky person is a remnant of the conquering race; a woman is the unlucky person according to Mr. Gomme; but if red-haired and splay. footed people, the qualtaghs were not likely to be women of the aboriginal race, i.e., assuming this race to have been a dark, small, high-instepped one. Assuming there is anything at all in the historical and ethnological explanation, why should unluckiness attach itself both to the conquering race and to the woman, 
who must be representative par excellence of the conquered race? A grave doubt is suggested whether the historical explanation is really the correct one. If it is, I then would emphasise this point. The whole of the lower beliefs and practices of this mixed race is shown to come from the prehistoric lower races. It is a conclusion with much to recommend it on a priori grounds, but we must look very cautiously at it; and when we find such objections as I have urged we must try and see if there are not other explanations.

Editorial.-We have received some information respecting the marks of the "qualtagh", or "first-foot", in other parts of Britain. We propose to print this in the next number, and we ask renders to send on, before the Ist of May, any information on the subject, derived either from personal knowledge or from books, they may have. Both the positive and negative signs of the qualtagh should be noted. When the information is from personal knowledze, exact localities and dates should be specified; when from books, not only should the bibliographical indications be full and accurate, but all the points mentioned by the writer should be given so as to obviate the need for further reference. Letters should be addressed to Mr. J. Jacobs, 4, Hazelmere Road, Kilburn, London, N.IV., and should be marked "First-foot" in the left-hand corner. 